\title{
Implante coclear: correlação da recuperação neural, privação auditiva e etiologia******
}

\author{
Cochlear implant: correlation of nerve function recovery, auditory \\ deprivation and etiology
}

\author{
Kellen Kutscher* \\ Maria Valéria S. Goffi-Gomez** \\ Débora Maria Befi-Lopes*** \\ Robinson Koji Tsuji**** \\ Ricardo Ferreira Bento*****
}

\begin{abstract}
*Fonoaudióloga. Pós-Graduada em Aprimoramento/Especialização em Implante Coclear pelo Hospital das Clínicas da Faculdade de Medicina da Universidade de São Paulo (HC FMUSP). Integrante do Grupo de Implante Coclear da FMUSP. Endereço para correspondência: Rua Capote Valente, 432, Conj. 14 - São Paulo - SPCEP 05409-001 (kellen@forl.org.br).
\end{abstract}

\section{**Doutora em Distúrbios da Comunicação Humana pela Universidade Federal de São Paulo (Unifesp). Integrante do Grupo de Implante Coclear do HC FMUSP.}

***Fonoaudióloga. Livre-Docente. Professora Associada do Departamento de Fisioterapia, Fonoaudiologia e Terapia Ocupacional da FMUSP.

****Otorrinolaringologista. Doutor em Otorrinolaringologia pela USP. Coordenador do Grupo de Implante Coclear do HC FMUSP.

******Otorrinolaringologista. Professor Titular do Departamento de Otorrinolaringologia da FMUSP. Integrante do Grupo de Implante Coclear do HC FMUSP.

******Trabalho Realizado no Programa de Aprimoramento em Implante Coclear do HC FMUSP.

Artigo Original de Pesquisa

Artigo Submetido a Avaliação por Pares

Conflito de Interesse: não

Recebido em 23.02.2010

Revisado em 04.08.2010; 09.08.2010.

Aceito para Publicação em 30.11.2010.

\begin{abstract}
Background: the Auditory Nerve Recovery Function (REC) may be extracted from the Electrically Evoked Compound Action Potential (ECAP). ECAP may be influenced by the stimulation received (or the deprivation of stimulation) and by the etiology of the hearing loss, consequently it might affect the REC. Aim: to verify whether there is a correlation between the REC and each of the following factors: etiology, time of auditory deprivation and time of hearing aid use before cochlear implantation (CI). Method: retrospective study. Data regarding etiology, time of auditory deprivation, time of hearing aid use before cochlear implantation were collected in children and adults who received a Nucleus ${ }^{\circledR} 24$. All patients who presented neural response at surgery and whose REC was assessed intraoperatively were included in this study. Fifty patients were selected, 26 children and 24 adults. Patients were divided according to the REC classification into three groups (GI: fast recovery; GII: intermediate recovery and GIII: slow recovery) to allow correlation analysis. Results: data analysis did not show any statistically significant correlation between the recovery function and the pre-implant studied characteristics. Nevertheless, it was observed that there was a greater concentration of both, children and adults, in the intermediate recovery function values. GI did not present individuals with infectious etiologies, such as meningitis, rubella and cytomegalovirus. REC average scores were slower in infectious etiologies for both children and adults. Conclusion: there was no statistically significant correlation between the recovery function and factors such as etiology, time of auditory deprivation and time of hearing aid use prior to CI. Key Words: Cochlear Implant; Telemetry; Refractory Period; Deprivation; Etiology; Deafness.
\end{abstract}

\section{Resumo}

Tema: a Função de Recuperação do Nervo Auditivo (REC) pode ser extraída do potencial de ação das fibras neurais - ECAP (Eletrically Evoked Compound Action Potential). O ECAP pode ser influenciado pela estimulação recebida pelo nervo e pela etiologia de uma perda auditiva e, consequentemente, afetar a REC. Objetivo: verificar se há correlação entre REC e os fatores: etiologia, tempo de surdez e tempo de uso do AASI antes do Implante Coclear (IC). Método: estudo retrospectivo transversal. Foram coletados dados sobre etiologia, tempo de surdez, tempo de uso do Aparelho de Amplificação Sonora Individual (AASI) e REC de 50 indivíduos, 26 crianças e 24 adultos, submetidos à cirurgia de IC e usuários do dispositivo multicanal Nucleus ${ }^{\circledR 24}$. As medidas da função de recuperação do nervo auditivo foram calculadas e os pacientes foram divididos em grupos (GI: recuperação rápida, GII: recuperação intermediária e GIII: recuperação lenta) para posterior análise de relação com os demais dados coletados. Resultados: a análise dos dados não mostrou correlação estatisticamente significante entre a recuperação e os aspectos pré-cirúrgicos estudados. Entretanto, foi possível observar maior concentração de ambos, crianças e adultos, nas REC intermediárias. GI não agrupou indivíduos com surdez de etiologias infecciosas, tais como a meningite, rubéola e citomegalovírus. A média de REC apresentou-se mais lenta para as etiologias infecciosas, tanto para o grupo de crianças, como para o grupo de adultos. Conclusão: não houve correlação estatisticamente significante entre função de recuperação do nervo auditivo e os fatores: etiologia, tempo de surdez e tempo de uso do AASI antes do IC.

Palavras-Chave: Implante Coclear; Telemetria; Período Refratário; Privação; Etiologia; Surdez.

\section{Referenciar este material como:}

1 Kutscher K, Goffi-Gomez MVS, Befi-Lopes DM, Tsuji RK, Bento RF. Cochlear implant: correlation of nerve function recovery, auditory deprivation and etiology (original title: Implante coclear: correlação da recuperação neural, privação auditiva e etiologia). Pró-Fono Revista de Atualização Científica. 2010 out-dez;22(4):473-8. 


\section{Introduction}

The auditory nerve recovery function (REC) may be extracted from electrically evoked compound action potentials (ECAPs), which may be influenced by stimulation received by the nerve and by the etiology of the hearing loss. Consequently, ECAPs may affect theREC $(1,2)$.

One way to evaluate the temporal processing ability of an individual with a cochlear implant (CI) is to measure the refractory properties of the auditory nerve, i.e., the recovery function of the auditory nerve through neural response telemetry (NRT) $(1,2,3)$.

The refractory properties of the auditory nerve are extracted from the amplitude of the neural response as a function of the interval between the stimulus and masking noise (i.e., the interpulse interval, or IPI) and can be measured by NRT using the subtraction method. The variation in the IPI allows for identification of the time that neural fibers remain in the refractory period (2).

Studies have shown variation in the threshold and growth curve of the wave amplitude of ECAPs (4-7) among individuals and etiologies $(4,5,6,8,9,10,11,12)$. Further research is necessary to correlate the refractory properties of the auditory nerve to the etiology of hearing loss, duration of deafness and responses to auditory nerve stimulation through the use of personal sound amplification products (PSAPs) before cochlear implantation.

Thus, the aim of this study was to investigate the correlation between the recovery function of the auditory nerve and the etiology of hearing loss, duration of deafness and duration of PSAP use in children and adults with multichannel CIs.

\section{Method}

A cross-sectional retrospective design was used in this study. Data were collected from the database of the Grupo de Implante Coclear do Hospital das Clínicas da Faculdade de Medicina da Universidade de São Paulo (HCFM-USP). Authorization to access the data was obtained prior to the study, which was approved by the local ethics committee (protocol 633/04).

Sample Selection:

Exclusion criteria:

- Individuals who had imaging study data showing partial insertion of electrode bundles and normal impedance tests in all modes of stimulation.

- Individuals with syndromes, auditory neuropathy and other neurologically associated damage.

- Absence of intra-operative ECAP.

Data regarding etiology of hearing loss, duration of deafness, duration of PSAP use and auditory nerve recovery function were collected before cochlear implantation in children and adults of both genders who received a Nucleus ${ }^{\circledR} 24$ (Cochlear Ltd., Australia) for monaural adaptation. The selection consisted of 50 individuals (26 children and 24 adults).

Procedure:

All individuals included in the present study were submitted to intraoperative neural response telemetry (NRT) and calculation and collection of the recovery function of the auditory nerve according to parameters proposed by Abbas et al. (1999) (1).

Data were characterized according to etiology of hearing loss, duration of deafness (in months) and duration of PSAP use (in months) before cochlear implantation.

The duration of deafness and duration of PSAP use were considered from the occurrence of severe and/or deep deafness in the implanted ear. For the correlation analysis, the etiology factor was grouped by non-infectious etiologies (the NIE group), which included congenital, perinatal and others and by infectious etiologies (the IE group), which included meningitis, rubella, cytomegalovirus and chronic otitis media (COM).

Measurements of the auditory nerve recovery function were obtained during cochlear implantation surgery using the NRT 3.1 software running on a DELL computer connected to the portable programming system (PPS) and a Sprint speech processor with a transmission antenna. Electrode 10 was used to stimulate, and electrode 12 was used to record the measurements (i.e., the neural responses).

The average level of current used for most of the recordings was 220 (range, 195-235). The stimulation current was adjusted to obtain the desired neural response (higher current) or to avoid saturating the amplifier (lower current). The amplifier gain parameters and delay used for this study were the same as those determined by the series of optimizations in the 80-Hz stimulation frequency of electrode 10 determined by Lai (1999) (13). In the case of impedance changes, lack of neural response or other impediments, the electrode most similar to electrode 10 was used (i.e., the electrode showing normal impedance and the presence of a neural response). 
The recovery function of the auditory nerve was scored according to the parameters proposed by Abbas et al. (1999) (1). The interpulse intervals (IPI) selected between the masking stimulus and the test stimulus were $500 \mu$ s and $2000 \mu$ s, respectively. The calculation of the recovery function of the auditory nerve was performed according to the formula:

Recovery function:

$($ REC $)=$ Amplitude response with IPI $=2000 \mu$ s X 100

Amplitude response with IPI $=500 \mu \mathrm{s}$

With the recovery function measurement of the auditory nerve, patients were divided into three groups according to the REC classification proposed by Abbas et al. (1999) (1): GI (average REC up to 20\%, fast recovery), GII (REC between 21 and 49\%, intermediate recovery) and GIII (REC ? 50\%, slow recovery).

Data analysis

The correlation between the recovery function of the auditory nerve and the factors etiology of hearing loss, duration of deafness and duration of PSAP use was performed using the REC average (absolute values) of the GI, GII and GIII groups. Statistical analysis of the groups was performed using the one-way ANOVA parametric test (statistical inference) and Pearson's correlation.

\section{Results}

Figure 1 shows the distribution of groups I, II and III.

We found that GII contained the largest concentration of patients (21-49\%; Fig. 1). This finding suggested that statistical analysis should be performed to verify the correlations using individual values of REC (as percentages).

Figures 2A and 2B show that the average REC for non-infectious etiologies (Group 1) was lower than the REC for infectious etiologies (Group 2); however, there was no statistically significant difference between REC values according to the etiology of hearing loss for children (Fig. 2A) or adults (Fig. 2B).

Pearson's correlation revealed no correlation between the duration of PSAP use and the duration of deafness or the REC variable for individuals of GII of both groups (children and adults). Pearson's correlations between duration of PSAP use and the REC for children and adults were $r=0.73$ and 0.07 , respectively. Finally, Pearson's correlations between duration of deafness and the REC for children and adults were $r=0.004$ and 0.09 , respectively.

It was not possible to analyze the correlation with the other groups (GI and GIII) presented by Abbas et al. (1999) (1) due to the small number of individuals in these groups. 
TABLE 1. Demographic distribution of the sample.

\begin{tabular}{|c|c|c|c|c|}
\hline Etiology & $\begin{array}{l}\text { Length of } \\
\text { deafness } \\
\text { (months) }\end{array}$ & $\begin{array}{c}\text { Time of } \\
\text { hearing aid } \\
\text { (months) }\end{array}$ & REC & Groups \\
\hline \multicolumn{5}{|c|}{ Children } \\
\hline $\begin{array}{l}\text { Cytomega lovirus } \\
\text { Inner Ear }\end{array}$ & 46 & 29 & 46.5 & GII \\
\hline Malformation & 42 & 17 & 18.5 & GI \\
\hline Rubella & 120 & 51 & 86.1 & GIII \\
\hline Ototoxicity & 37 & 25 & 40.4 & GII \\
\hline Unkn own & 27 & 20 & 58.4 & GIII \\
\hline Ototoxicity & 18 & 8 & 60.1 & GIII \\
\hline Unknown & 61 & 25 & 55.1 & GIII \\
\hline Ototoxicity & 39 & 29 & 38.5 & GII \\
\hline Unkn own & 24 & 12 & 35 & GII \\
\hline Unknown & 14 & 5 & 44.7 & GII \\
\hline Unkn own & 74 & 32 & 35.3 & GII \\
\hline Unknown & 26 & 9 & 53.9 & GIII \\
\hline Unknown & 47 & 17 & 32.4 & GII \\
\hline Ototoxicity & 60 & 48 & 26.3 & GII \\
\hline Unkn own & 38 & 15 & 24.7 & GII \\
\hline Ototoxicity & 60 & 36 & 46.7 & GII \\
\hline Unkn own & 20 & 5 & 28 & GII \\
\hline Unknown & 33 & 11 & 25.8 & GII \\
\hline Men ingitis & 36 & 26 & 33.5 & GII \\
\hline Cytomega lovirus & 19 & 8 & 31.2 & GII \\
\hline Men ingitis & 156 & 150 & 77.4 & GIII \\
\hline Men ingitis & 36 & 25 & 42.1 & GII \\
\hline Unknown & 11 & 6 & 12.7 & GI \\
\hline Anoxia & 84 & 69 & 32.1 & GII \\
\hline Ototoxicity & 30 & 3 & 61 & $\overline{\text { GIII }}$ \\
\hline Men ingitis & 29 & 5 & 34.4 & GII \\
\hline \multicolumn{5}{|c|}{ Adults } \\
\hline Unkn own & 332 & 3 & 24.2 & GII \\
\hline Unknown & 36 & 3 & 26.1 & GII \\
\hline Traumatic & 12 & 3 & 47.7 & GII \\
\hline Unknown & 312 & 120 & 43.3 & GII \\
\hline Unknown & 36 & 36 & 44.8 & GII \\
\hline Otosclerosis & 132 & 3 & 31.1 & GII \\
\hline Otosclerosis & 36 & 36 & 25.1 & $\overline{\text { GII }}$ \\
\hline Men ingitis & 324 & 3 & 55.9 & GIII \\
\hline Men ingitis & 96 & 3 & 32.7 & GII \\
\hline Ototoxicity & 204 & 180 & 31.4 & GII \\
\hline Unkn own & 36 & 3 & 34.7 & GII \\
\hline Unkn own & 36 & 3 & 23.5 & GII \\
\hline Unknown & 228 & 228 & 15 & GI \\
\hline Men ingitis & 300 & 300 & 29.5 & GII \\
\hline Au toimmune & 36 & 36 & 43.4 & GII \\
\hline Men ingitis & 204 & 204 & 40.3 & GII \\
\hline Hereditary & 444 & 240 & 39.7 & GII \\
\hline Otosclerosis & 36 & 36 & 25.1 & GII \\
\hline Men ingitis & 228 & 3 & 30.3 & GII \\
\hline Traumatic & 48 & 3 & 39.8 & GII \\
\hline \multicolumn{5}{|l|}{ Chron ic Otitis } \\
\hline Media & 216 & 3 & 50 & GIII \\
\hline Rubella & 240 & 133 & 33.8 & GII \\
\hline Otosclerosis & 24 & 24 & 75.1 & GII I \\
\hline Otosclerosis & 48 & 48 & 26 & GII \\
\hline
\end{tabular}


FIGURE 1. Distribution of REC values in percentage for all groups (children and adults).
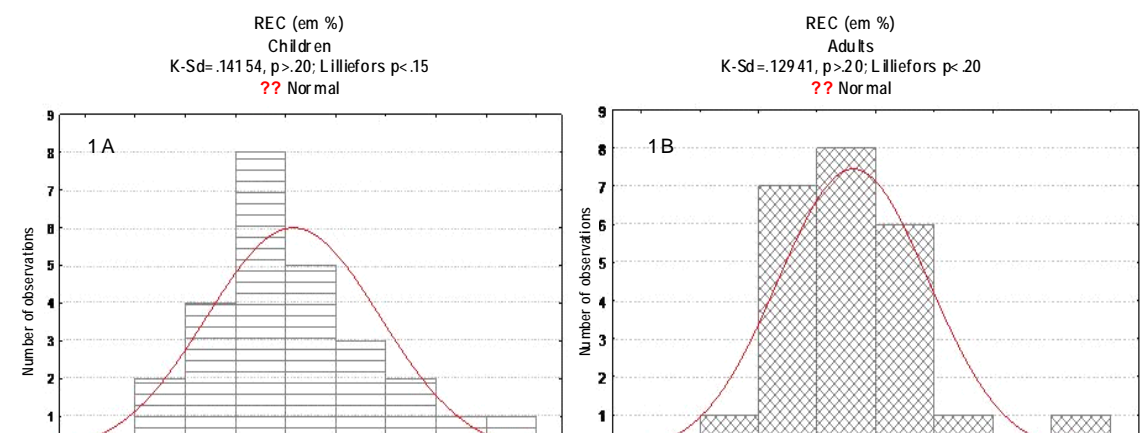

FIGURE 2. Results and one-way ANOVA on REC values between infectious (IE) and non-infectious etiologies (NIE)
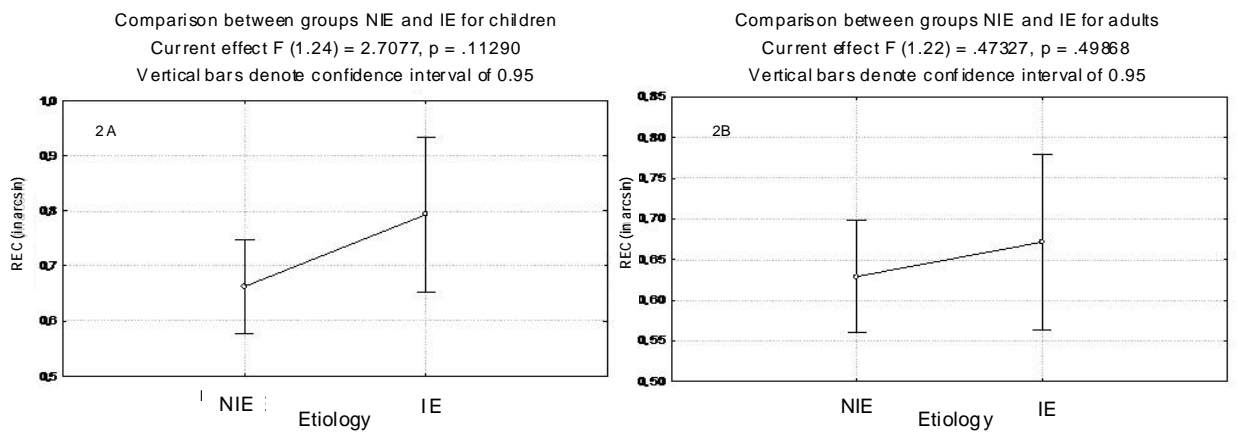

\section{Discussion}

Based on the statistical analysis, it was possible to conclude that the etiology, duration of deafness and duration of PSAP use influenced the recovery function of the auditory nerve; however, there was no statistically significant correlation between these factors. It is important to note that samples were centered in the intermediate REC and that GI consisted of a reduced number of individuals (Fig. 1).

The recovery function of the auditory nerve showed no statistically significant correlation with the etiology of hearing loss; however, the frequency distribution of the etiology in each group (GI, GII and GIII) may have interfered with the results. Conversely, we observed a faster REC tendency in those with non-infectious etiologies. In these patients, this trend may be revealed using a larger sample.

In addition to having a small number of individuals, GI did not contain patients with infectious etiologies such as meningitis, rubella and cytomegalovirus. The averages of REC values were greater for infectious etiologies for both children and adults (Fig. 2). This finding may justify the hypothesis in this study that the intermediate and slow neural fibers of the auditory nerve may be associated with infectious etiologies. Several studies have suggested a possible relationship between the meningitis and abnormalities in auditory neural functioning $(4,5,6,7,9)$. Wellman et al. (2003) (12) observed, in temporal bones, that hearing loss caused by meningitis resulted in labyrinthine ossification, reduction of spiral ganglion neurons and involvement of auditory nerve fibers. Miura et al. (2002) (10) reported that deafness resulting from infectious processes or changes (such as rubella and cytomegalovirus) can result in a reduction of ganglion cells in relation to other etiologies. Pyman et al. (2000) (11) reported that cytomegalovirus was a possible factor related to poor speech perception in children using CIs. 
Regarding the duration of deafness, an increase in duration was observed in GI, GII and GIII; however, no significant difference was detected between the groups. Thus, there may be a tendency for a faster neural recovery function when the duration of deafness is shorter (Table 1 ). The duration of deafness has been identified as one of the factors related to changes or absence of action potentials in the auditory nerve (3) and a factor influencing speech production and perception, as well as language developmenter in CI users (14).

Adults who show a shorter duration of deafness may present a lower number of changes in the temporal processing properties of the estimated neural population, and consequently may help determine a better result with the use of a CI (15). According to Gomaa et al. (2003) (15), it is important to consider the predictability of the result of using a CI in relation to duration of deafness and speech perception abilities. The preoperative residual speech recognition acts as a "trophic factor," and it protects the spiral ganglion and/or the central auditory pathways from degeneration.

GIII had the shortest duration of PSAP use, which should be taken into account in the clinic. That is, individuals who presented with slow recovery were those who had used PSAPs for less

\section{References}

1. Abbas PJ, Brown CJ, Shallop JK, Firszt JB, Hughes ML, Hong SH, Stallen SJ. Summary of Results Using the Nucleus CI24M Implant to Record the Electrically Evoked Compound Action Potential. Ear Hear. 1999;20(1):45-9.

2. Ferrari, DV, Sameshima, K. Costa-Filho, O.A. Bevilacqua, M.C. A telemetria de respostas neurais no sistema de implante coclear multicanal nucleus 24: revisão da literatura. Rev Bras Otorrinolaringol. 2004;70(1):112-8.

3. Abbas PJ, Brown CJ, Hughes ML, Gantz BJ, Wolaver AA, Gervais JP, Hong SH. Electrically evoked compound action potentials recorded from subjects who use the nucleus CI24M device. Ann Otol Rhinol Laryngol Suppl. 2000;185:6-9.

4. Cafarelli Dees D, Dillier N, Lai WK, von Wallenberg E, van Dijk B, Akdas F, Aksit M, Batman C, Beynon A, Burdo S, Chanal JM, Collet L, Conway M, Coudert C, Craddock L, Cullington H, Deggouj N, Fraysse B, Grabel S, Kiefer J, Kiss JG, Lenarz T, Mair A, Maune S, Müller-Deile J, Piron JP, Razza S, Tasche C, Thai-Van H, Toth F, Truy E, Uziel A, Smoorenburg GF. Normative findings of electrically evoked compound action potential measurements using the neural time, which may suggest the possible influence of PSAPs in stimulating the auditory nerve fibers (Table 1). This finding is consistent with the findings by Tremblay (2007) (16), who reported that cochlear lesions result in a neural reorganization (i.e., plasticity) along the auditory pathway. Given that hearing aids reintroduce auditory stimulation via amplification, this may imply the occurrence of "new" plasticity in the central auditory system.

The fact that there was no statistical correlation between preoperative data and the REC leads us to wonder whether the recording of the recovery function using the methodology proposed by Abbas et al. (1999) (1) is sensitive and specific. In fact, the study by Miller (2008) (17) reports new research regarding ECAP measures, as well as implications of possible methods, interpretations and neural function.

Further investigations are needed to identify possible factors associated with the REC function of the auditory nerve in CI users and its clinical implications.

\section{Conclusion}

There was no statistically significant correlation between recovery function of the auditory nerve and factors such as etiology of hearing loss, duration of deafness or duration of PSAP use prior to cochlear implantation. response telemetry of the Nucleus CI24M cochlear implant system. Audiol Neurootol. 2005;10(2):105-16.

5. Guedes MC, Brito-Neto RV, Sanchez TG, Gomez VG, Sant'Anna SBG, Peralta CO, Castilho AM, Bento RF. Medidas de telemetria de resposta neural em utilitários de implante coclear multicanal. Arqui Otorrinolaringol. 2003; 7:197-204.

6. Guedes MC, Weber R, Goffi-Gomez MVS, Brito Neto RV, Peralta CGO, Bento RF. Telemetria de resposta neural intraoperatória em usuários de implante coclear. Rev Bras Otorrinolaringol. 2005;71(5):660-7.

7. Blamey PJ, Sarant JZ, Paatsch LE, Barry JG, Bow CP, Wales RJ, Wright M, Psarros C, Rattigan K, Tooher R. Relationships among speech perception, production, language, hearing loss, and age in children with impaired hearing. J Speech Lang Hear Res. 2001;44(2):264-85.

8. Guedes MC, Weber R, Goffi-Gomez MVS, Brito Neto RV, Peralta CGO, Bento RF. Efeitos do potencial de ação neural sobre a percepção de fala em usuários de implante coclear. Rev Bras Otorrinolaringol. 2007;73(4):660-7. 
9. Jiang ZD. Outcome of brain stem auditory electrophysiology in children who survive purulent meningitis. Ann. Otol. Rhinol. Laryngol. 1999; 108: 429-34.

10. Miura M, Hirsch BE, Sando I, Orita I. Analysis of ganglion cell population in children with normal and pathological ears. Ann Otol Rhinol Laryngol. 2002;111 (2pt1):1059-65.

11. Pyman B, Blamey P, Lacy P, Clark G, Dowell R. The development of speech perception in children using cochlear implants: effects of etiologic factors and delayed milestones. Am J Otol. 2000;21(1):57-61.

12. Wellman MB, Sommer DD, McKenna J. Sensorineural hearing loss in postmeningitic children. Otol Neurotol 2003; 24(6):907-12.

13. Lai W, An NRT. Cookbook: Guidelines for making NRT measurements. 1st ed. Zürich: Cochlear AG; 1999.
14. Moret ALM, Bevilacqua MC, Costa OA. Implante coclear: audição e linguagem em crianças deficientes auditivas pré-linguais. Pró-Fono 2007;19(3):295-304.

15. Gomaa NA, Rubinstein JT, Lowder MW, Tyler RS, Gantz BJ. Residual speech perception and cochlear implant performance in postlingually deafened adults. Ear Hear. 2003;24(6):539-44.

16. Tremblay K, Ross B. Effects of age and age-related hearing loss on the brain. J Commun Disord. 2007; 40(4):305-12.

17. Miller, CA, Hui N, Zhangi F, Robinsoni BK, Abbas PJ. Changes Across Time in the Temporal Responses of Auditory Nerve Fibers Stimulated by Electric Pulse Trains. 2008;9:122-137. 